\title{
Drug resistance patterns in new and previously treated patients with tuberculosis presenting to a tertiary care center in southern India
}

\author{
Anto J Udaykumar', Jayashree R², Baijayanti Mishra², Rosario Vivek', John Kenneth ${ }^{1 *}$ \\ From 2nd International Science Symposium on HIV and Infectious Diseases (HIV SCIENCE 2014) \\ Chennai, India. 30 January - 1 February 2014
}

\section{Background}

Tuberculosis (TB) caused by Mycobacterium tuberculosis remains a major global health problem. It is the second leading cause of death worldwide. Drug resistance threatens global TB control with the emergence of multidrug resistant (MDR) and extensively drug resistant (XDR) TB. The burden of MDR TB and XDR TB in India is not available as continuous surveillance for drug resistance is not carried out. This study was done to determine the drug resistance patterns to first and second line drugs among new and previously treated patients with TB.

\section{Methods}

Sputum samples were collected from 100 suspected TB patients from a tertiary care referral hospital. After digestion and decontamination, samples were stained for microscopy and cultured in liquid (MGIT) and Löwenstein Jensen (LJ) medium to isolate M. tuberculosis. Drug susceptibility testing (DST) was done against first line (streptomycin, isoniazid, rifampin and ethambutol) and second line (kanamycin, capreomycin, ofloxacin and ethionamide) drugs.

\section{Results}

Among the 100 samples, 56 were smear positives and M. tuberculosis was isolated from 61 samples cultured in MGIT and 46 in L J medium. Of which 20 (32.7\%) were MDR strains. Among the MDR strains, 9 (45\%) were XDR strains. Two strains were totally resistant to all the 8 drugs. The proportion of MDR and XDR was highest among the previously treated patient.

\footnotetext{
* Correspondence: johnkennet@gmail.com

'Division of Infectious Diseases, St. John's Research Institute, Bangalore 560034, India

Full list of author information is available at the end of the article
}

\section{Conclusion}

This study underscores the need for DST in all TB patients particularly in the previously treated patients. New drugs, novel treatment strategies and adherence to treatment are needed to effectively treat and control drug resistant TB.

\section{Authors' details}

'Division of Infectious Diseases, St. John's Research Institute, Bangalore 560034, India. ${ }^{2}$ Department of Microbiology, St. John's Medical College Bangalore 560034, India.

Published: 27 May 2014

doi:10.1186/1471-2334-14-S3-O3

Cite this article as: Udaykumar et al:. Drug resistance patterns in new and previously treated patients with tuberculosis presenting to a tertiary care center in southern India. BMC Infectious Diseases 201414 (Suppl 3):03.
Submit your next manuscript to BioMed Central and take full advantage of:

- Convenient online submission

- Thorough peer review

- No space constraints or color figure charges

- Immediate publication on acceptance

- Inclusion in PubMed, CAS, Scopus and Google Scholar

- Research which is freely available for redistribution

Submit your manuscript at www.biomedcentral.com/submit
C Biomed Central 